\title{
Conversational maxims in fiction translation: New insights into cooperation, characterization, and style
}

\author{
Othman Ahmad Abualadas \\ Department of English Language and Literature, Faculty of Languages, The University of Jordan-Aqaba
}

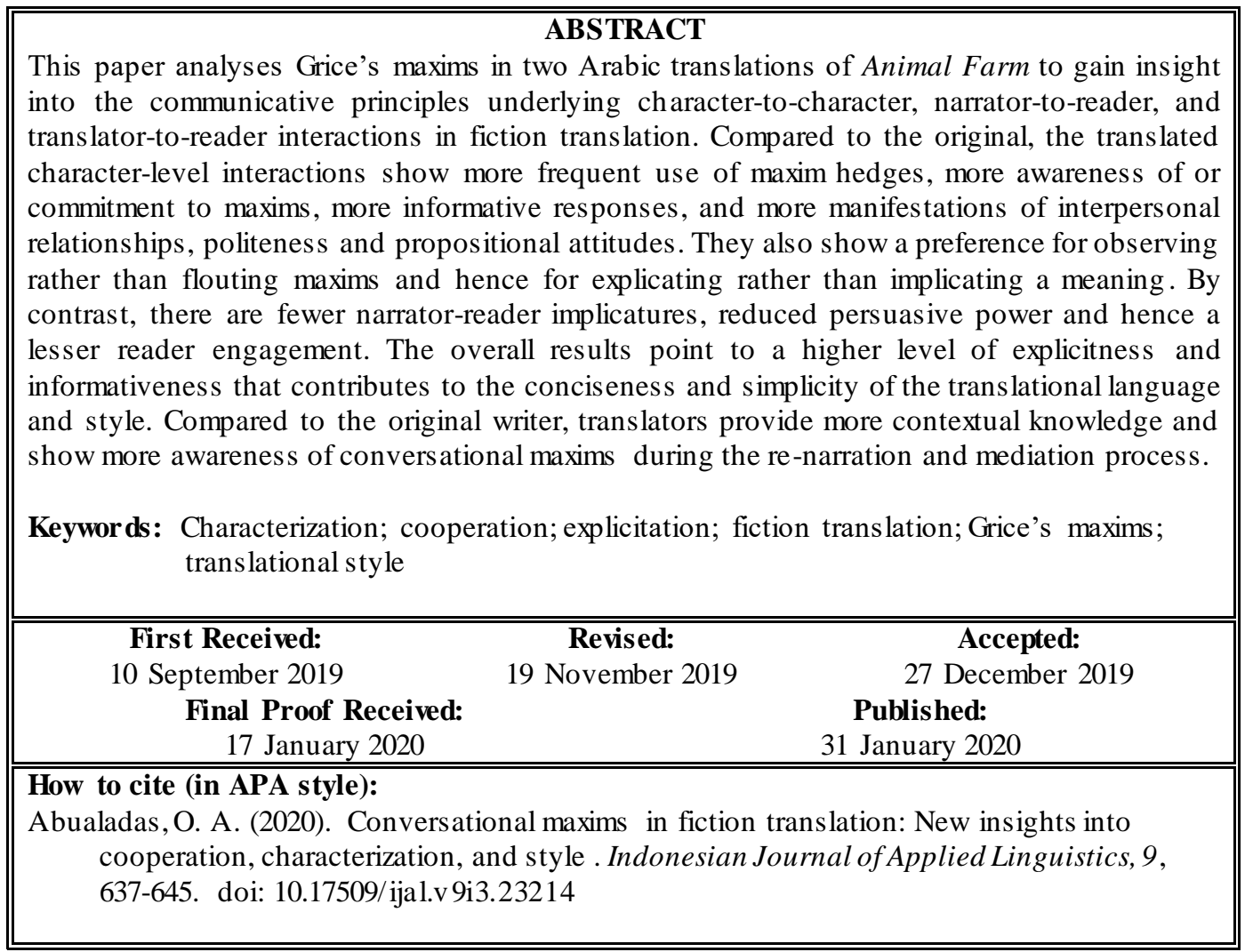

\section{INTRODUCTION}

This paper examines two Arabic translations of George Orwell's Animal Farm (1945), adopting an analytical framework based on Grice's theory of Cooperative Principle (CP) (1975). More particularly, it analyses the patterns of change in the translation of conversational maxims and their potential effect on meaning-creation and inferencing processes in the translated narrative (Malmkjær, 2005; Gutt, 2010; Levý, 2011; Abualadas, $2019 b, 2019 c)$. One important argument the present paper makes is that the analysis of conversational maxims enables us to stylistically interpret interactions and relationships between (i) the characters themselves (ii) the narrator and characters, (iii) the narrator and reader (Black, 2006; Leech \& Short, 2007) and (iv) the translator and reader (Munday, 2008; Boase-Beier, 2014). Not only as a device for the analysis of the implicit/intended message, conversational maxims can be used also as a stylistic characterization tool for the exploration of characters (Culpeper, 2014; see Bousfield, 2014, pp. 130-131); the exploration of conversational behaviours that reflect the characters' "individual characterisations and their characterrelations" and their propositional attitudes (Leech \& Short, 2007, p. 269).

In this theoretical framework, conversational maxims can be exploited to analyse the translator's mediating presence (Malmkjær, 2004) and its effect on the stylistic characteristics of the translated narrative (Munday, 2008) as well as its effect on the target reader's cognitive engagement with the translated narrative (Boase-Beier, 2018). If we assume that "the message coming from the translation is relayed in a different code ["a third code" in Frawley's words (1984, p. 168)] that bears the translator's print" (Munday, 2008, p. 13), exploiting speech maxims will enable us to approach the conversational rules or interactional patterns pertinent to that code. The findings of present 
study will help enhance fiction translators' awareness of the dynamic role of conversational maxims in interpretation and translation, and enhance translators' understanding of the "cognitive-referential" and "interpersonal" functions of the translated language (House, 1998, p. 56). The findings will also shed light on the important role that pragmatics-oriented models play in the research into "translational stylistics" (Malmkjær, 2003, see Şerban, 2013, pp. 217-221).

\section{Conversational maxims and cooperation}

Grice (1975) studied cooperation in conversation: how people communicate cooperatively and proposed the notion of conversational maxims. His basic view is that communication is a cooperative and joint activity where both speakers and hearers cooperate to reach certain common goal(s) (see Lambrou, 2014, p. 142). When interpreting any utterance, the hearer assumes that the speaker has complied with certain maxims concerning the truth, informativity, clarity and relevance of the information exchanged. When we talk, we are actually assumed to give sincere, sufficient, relevant, and clear information; and hearers are expecting us to do so. Grice (1975, pp. 45-47) proposes four major maxims, as shown in Figure 1, that speaker is assumed to comply with (which together comprise the Cooperative Principle (CP)).

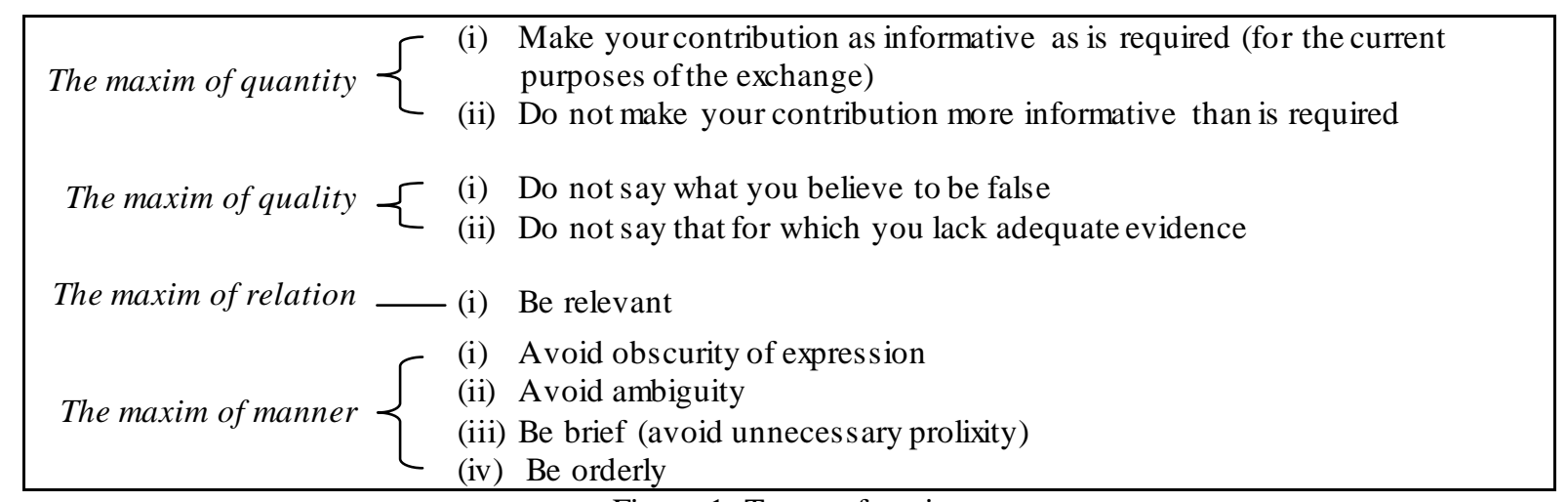

Figure 1. Types of maxims

According to Grice, the maxims are the ground rules that people normally observe when they speak and interpret utterances (Black, 2006, p. 23). When A asks $\mathrm{B}$, "How is your new job?" and B replies, "Everything is OK, thank you," A expects B to observe the maxims: by giving an answer that is conventionally sufficient, truthful, relevant to the question being asked and perspicuous. Speakers may not always observe these speech maxims; they may exploit or flout them. This happens when we strategically break a maxim to give an additional meaning in an indirect way; when we blatantly fail to observe a maxim to draw the hearer's attention to a different meaning. This happens when we say something that is more or less than needed, or give information that is untrue, irrelevant or ambiguous, while expecting the hearer to cooperatively search for the intended meaning (see Leech, 2014, pp. 74-78). An example is when A asks B "How is your new job?" and B replies "Get lost!" or "Can you help me find another job," which flagrantly flouts the maxim of relation and manner and gives the meaning that "B is not happy with his new job."

Another case of ostentatious flouting of speech maxims is the use of figurative expressions such as metaphors, tautologies, idioms, irony and hyperbole. The metaphorical expression "War is war" is a flouting of the maxim of quantity (by giving information less than needed) and manner (by saying something unclear), while the expression "Intelligence is a doubleedged sword" is a flouting of the maxim of quality (by saying something untrue) as well as the maxim of manner. The use of such figurative language induces the listener to go beyond the literal meaning and search for the intended meaning. Grice referred to this intended meaning, which has to be inferred as conversational implicature. It is this conversational implicature that bridges the gap between what is stated (the literal content, determined by the grammatical structure) to what is implicated by the speaker (Horn, 2006, p. 3).

In addition to flouting maxims, there are some cases when speakers express their awareness of the maxims by using an extra note, called hedge. When we speak, we may simply make an assertion like "alcohol is not good for your health," but if we are hesitant to make such a bald assertion, we may preface it with a hedge on the quantity of information like "as far as I know" or "all what I know." These hedges reflect to the hearer that we are aware of the maxim of quantity and that our utterance may or may not adhere to this maxim. Grundy (2013, pp. 100-101) argues that such hedges do not add any truth-value to the sentence they are attached to; they are more a comment on the extent to which we are adhering to the maxims in our speech than a part of our speech. Examples on quality hedges include expressions that indicate that the speaker is not sure about the truth of his/her utterance such as "I believe" or "I think". Relevance hedges involve for instance expressions that indicate a sudden change in the topic like "anyway" or "by the way". Manner hedges can involve such expressions as "more simply" or "more clearly".

Grice's conversational maxims have helped stylisticians to analyse how "conversational norms 
become resources for meaning-making upon which authors draw in the design of represented dialogue and narrative" (Warner, 2014, pp. 369). Even though Grice's theory of conversational maxims and implicature was first proposed in relation to shortspoken dialogues, it has proven useful for the interpretation and linguistic analysis of large literary texts (Warner, 2014, pp. 368-369). As a literary text, such as a play or novel, may largely contain conversations between characters, these conversations should also be analysable by some of the same models of analysis that are applicable to any real-life language interactions (Bousfield, 2014, pp. 118-119). Communications between fictional characters are often mimetic of the real-life interactions, where characters may exaggerate, lie, hide or avoid giving certain information (see Leech \& Short, 2007, pp. 296-298). Since Gricean maxims are of relevance for the analys is of fictional discourse, we may expect the maxims to be also relevant to the analysis of the interactions between characters or between the narrator and characters (Black, 2006, p. 27; Lambrou, 2014, p. 145).

Grice's theory of speech maxims has been criticized for ignoring some other issues relevant to meaning processing, most importantly social and interpersonal relations (Black, 2006, p. 24, see Bach, 2012, p. 57). Grice's theory does not also account for stylistic variations in text types as well as cross-linguistic and cross-cultural differences. Sperber and Wilson (1995) question the need for four different conversational maxims to account for meaning. They argue that since every utterance is processed only on the ground that it is relevant to the current language exchange, Grice's maxims should be reduced to a single maxim, that of relevance (Be relevant). Leech (2014) adds a fifth maxim, that of politeness (be polite). He argues that politeness maxim, which concerns showing consideration to others, has a higher status than Grice's maxims and therefore enables us to explain interactions where other maxims are flouted for interpersonal reasons.

\section{Conversational maxims and translation}

The notion of speech maxims has been employed in descriptive translation studies to indicate the need to analyze the extra-textual parameters influencing meaning generation processes in translation (Malmkjær, 2005; Morini, 2008; Gutt, 2010). The notion of speech maxims has been used to raise translators' awareness towards the question of how people interact through texts, and how they construct and negotiate their intentions, identities or feelings (Şerban, 2013, p. 220). Lockwood in Wuthering Heights uses the expression "What vain weathercocks we are" (Chapter 4) to describe the sudden change in his personality; he has been a misanthrope and now has become more interested in getting closer to people. He chooses to communicate his attitudes to readers by speaking metaphorically, flouting the maxim of quality (by giving false information; no one can be a weathercock in reallife) and manner (by speaking in an unclear way).

Some studies adopting a pragmatic and textlinguistic model of translation have emphasized that understanding how speech maxims operate in a text is fundamental for determining its overall organization and maintaining its coherence (e.g., Blum-Kulka, 2004; Hatim \& Mason, 2013). The utterance "I lost ten thousand dollars in the casino. What a lucky night!" will not sound coherent unless we realize that the speaker in the second clause is flouting the maxim of quality to create a pragmatic effect, irony or sarcasm (see Baker, 2018a, pp. 249-154). The basic assumption that translators need to understand here is that the grouping of sentences in a particular situation or text is not often random; a speaker or writer has put these sentences in a particular way or order intentionally for communicative purposes (Shreve, 2018, p. 165).

Grice's maxims have been used in translation studies to point out the complex communicative principles that require the translators to understand a range of linguistic, social, cultural, and sometimes psychological dimensions (Ying \& Zhao, 2018, pp. 117118). These maxims should not be looked at as rules for how to speak properly; they are more like general norms, which are often breached in order to communicate messages in an indirect way, "the actual maxims might vary enormously from culture to culture" (Pym, 2014, p. 35). Cultures show differences as to how and when an utterance in a given situation is, or is not, sufficient, truthful, relevant, clear and polite (see Wierzbicka, 2003, pp. 392-403). Several studies have actually emphasized the differences between cultures and societies in how these maxims operate and how they rank with respect to each other (e.g., Malmkjær, 2005; Morini, 2013; Baker, 2018a). For instance, in Arabic-language cultures, the maxim of politeness in spoken and written communications tends to have more value or weight than the other maxims; the consideration of people's face often overrides the consideration of the information quantity, quantity, relevance or clarity (Baker 2018a, pp. 251-252). Also, sarcasm is likely achieved in many Arabic-language cultures more through flouting the maxim of quantity than the other maxims (Hatim, 2000, pp. 196-197). This reflects a cross-cultural variation in the ways these maxims operate, and which can only make the task of translation harder.

Analyzing how conversational maxims operate in a text can contribute to the characterization of style, "the perceived distinctive manner of expression in writing or speaking" (Wales, 2014, p. 397), helping the translator in maintaining a close stylistic link with the original text (Boase-Beier, 2014, p. 394). Analyzing how meaning is constructed or generated via maxims in a fictional text assists the translator in both hearing and recreating the literary style or narrative voice that guides the linguistic choices made by the author (Munday, 2008, p. 19). Such analysis would help fiction translators in maintaining the style of the original as to how the 
original author communicates messages to his/her readers and how the narrator and characters in the original narrative interact among themselves. The process of reading a text involves interpreting implicatures triggered through maxims; it demands active processing or interpretative efforts (engagement) on the reader's part. This reader engagement may be determined, among other factors, by such stylistic features of the text as the tendency to flout rather than observe maxims or more generally the tendency to communicate in an implicit rather than explicit way. The translator's awareness of maxims would then help in constructing a translation that provokes a level of reader engagement similar to that of the original (Boase-Beier, 2018, p. 201). The analys is of interaction using maxims would also provide insights into the study of the reader engagement with the translated text.

\section{METHODS}

The source and target texts and methodological issues

The source text is George Orwell's novel Animal Farm (1945). George Orwell was an English novelist and political satirist who opposed Russian communism and defended freedom and democratic socialism. His novel Animal Farm is a political satire of Stalinism and the Russian Revolution of 1917. It mocks the outcomes of the Russian Revolution; when the revolution has led to a government that is far worse than the one it has overthrown. The story revolves around a group of animals who decided to kick their master, Jones Manor, and his men out of the farm they live on and adopt their own philosophy of life, called Animalism. After they manage to achieve their goals, the life in the farm improves for a while, but it shortly starts to get worse when two young pigs, Napoleon and Snowball, seize control of the farm and start to fight for power. Over the years, other animals' life becomes more miserable, and when Napoleon eventually defeats Snowball, he and his fellow pigs start to dress and behave like Jones and his men. The story ends when the pigs seem to adopt the same role as that of the humans the animals once revolted.

Animal Farm has a distinctive writing style. A third-person omniscient narrator who relates information from the perspective of multiple animals narrates the story. The narrator is not involved in the story events, but has a god-like access to their subjective knowledge and emotions (see Bloom, 2006). Orwell in this novel uses a simple and concise language. He adopts a spare linguistic style that is often described as unambiguous, direct, exact, and impersonal, with simple and clear syntactic structures and plain and demotic lexical choices (Fowler, 2009, pp. 63-68). Orwell's style in this novel is also characterized by the use of ironic language that reflects his sarcastic views of the Russian Revolution.

The target texts that are analysed and compared in the present study are Abada (2009) and Abdulghani (2014), which, to the researcher's knowledge, are the only Arabic translations of the novel. Both translations are well known to Arab readers and critics, and are taught in several language and literature courses in many universities in the Arab World. Both translators are Arabic native speakers and well known in the field of English-Arabic fiction translation. For the analysis process, the study has utilized a descriptive model (Toury, 2012) in which the maxims governing the interactions between interlocutors (the narrator, characters and readers) are compared and described in both source and target texts. The study has analyzed any kind of deviation from the original in the way(s) the maxims operate or are utilized (e.g., observed, flouted or hedged, etc.) by interlocutors. Relying on evidence from the textual analysis (see Mason, 2000, p. 18; Şerban, 2013, p. 219), the study has tried to describe the potential effect of this deviation on the communicative behaviours and interpersonal relations in the story. The study assumed that the translated text is often "the result of motivated choices" and hence can be "a means of retracing of the pathways of the translator's decisionmaking procedures" (Hatim \& Mason, 2013, p. 4). Therefore, the study has employed textual data to describe the translator's (intentional or unintentional) choices or mental processes underlying the changes in the communicative behaviours in the translated story (see Abualadas, 2019a, pp. 74-75).

\section{RESULTS AND DISCUSSIONS Analysis of data}

The study has compared the two target texts with the original text and examined any change in the way Grice's maxims are operating in the interactions between characters or between the author/narrator and reader. As can be seen in Table 1, the study has found that Grice's maxims have undergone four kinds of change in translation.

Table 1. Changes in Grice's Maxims in the Two Translations

\begin{tabular}{lccr}
\hline Changes in translation of maxims & Abada & Abdulghani & Total \\
\hline Hedging maxims & 48 & 25 & 73 \\
Observing maxims flouted in the original & 34 & 20 & 54 \\
Increasing information quantity & 37 & 28 & 65 \\
Flouting maxims observed in the original & 2 & 4 & 6 \\
Total & $\mathbf{1 2 1}$ & $\mathbf{7 7}$ & $\mathbf{1 9 8}$ \\
\hline
\end{tabular}

The first kind of change, hedging maxims, involves the insertion into the translated narrative of different hedges on different maxims that do not exist in the original narrative. The translator here, whether intentionally or unintentionally, adds a particular cautious note indicating that the speaker is aware of the maxim 
guiding the interaction. Among the 73 cases of hedges added by the translators, 31 are hedges on the maxim of relevance, 18 hedges on quality, 13 hedges on quantity, while 11 hedges on manner. The following examples explain how these hedges occur in the translations. Note that the Library of Congress Transliteration System is used transliterate the Arabic text (see appendix). An English gloss of the Arabic text is offered to allow nonArabic readers to see the changes and follow the discussions. The underlined sentences indicate the English translated parts within examples. Italic font is used for emphasis.

1. S T: The very first question she asked Snowball was, "Will there still be sugar after the Rebellion?"

"No," said Snowball firmly. "We have no means of making sugar on this farm. Besides, you do not need sugar. You will have all the oats and hay you want." (Orwell, 1945, Ch.2)

TT: 'alā kuli ḥālin, al-sukaru shay’un ghayru ḍarūrī. (Abdulghani, 2014, p. 27)

[Gloss: By the way, sugar is not an important thing]

2. ST: "We have removed the sheets from the farmhouse beds, and sleep between blankets. And very comfortable beds they are too!" (Orwell, 1945, Ch. 6)

TT: wa-'aqrāran li-al-ḥaqi fa-'anna al-nawma 'alā al-sarīi murīhun jidan. (Abada, 2009, p. 59)

[Gloss: and to say the truth, sleeping in bed is very comfortable]

3. ST: "The enemy was in occupation of this very ground that we stand upon. And now-thanks to the leadership of Comrade Napoleon-we have won every inch of it back again!"

"Then we have won back what we had before," said Boxer. (Orwell, 1945, Ch. 8)

TT: kull mā fī al-’amri 'ananā 'asta‘dnā (thānīyan) mā kāna lanā min qabl! (Abada, 2009, p. 89)

[Gloss: the whole issue is that won back what we had before!]

4. ST: "What is going to happen to all that milk?" said someone.

"Jones used sometimes to mix some of it in our mash," said one of the hens.

(Orwell, 1945, Ch. 2)

TT: wa-'almaḥat al-firākhu 'anna mistir jūnz 'a'tāda 'ann yamzija al-'alafa al-khāṣu bi-hā bi-shay'in mina al-llaban! (Abada, 2009, p. 25)

[Gloss: and the hens hinted that Mr. Jones used to mix their mash in some milk!]

In Example (1), Mollie, a vain mare who prefers sugar over rebellion, wonders if she will get to eat sugar after rebellion, and Snowball reminds her that she will have better options; oat and hay. In the given translation, the expression "Besides" has been replaced by "by the way", which is a hedge on the maxim of relation; it shows that Snowball is warning Mollie that his utterance "you do not need sugar" may or may not be relevant to her question. In Example (2), the horse Clover is disturbed after hearing that the pigs have moved into the farmhouse and begun sleeping in beds too, and the pig Squealer explains to her that the pigs have done so only because they need a quiet place to think clearly. The given translation has prefaced Squealer's utterance "And very comfortable beds they are too" by the expression "to say the truth". This shows that Squealer hedges the maxim of quality; where he explicitly expresses to Clover his awareness that his response must be well founded and that he is fully committed to the truth of his utterance.

In (3), the animals manage to defeat Frederick and his men who have just attacked the farm and blown up the windmill, and Squealer claims that this is a victory, but the horse Boxers does not think so. Boxers responds to Squealer that what we just did is that "we have won back what we had before". However, in the given translation, the hedge "the whole issue is" has prefaced Boxers' response. This is a hedge on the maxim of quantity, which conveys Boxers' concern over the most precise information, which he has to give while speaking to Squealer. In (4), When the pigs milk the cows and produce five pails of milk, which later the pig Napoleon steals, the other animals wonder what the pigs are going to do with this milk. A hen, who eyed the milk desirously, says to Napoleon that Jones used to mix it in their mash. In the given translation the whole mode of report has been changed from direct speech into indirect speech (see Leech \& Short, 2007, pp. 255-257), where also the verb used to report the hen's utterance, "said", has been replaced by the verb "'almahat" (hinted, said indirectly). The use of the reporting verb "'almahat" is a hedge on the maxim of manner; which reflects that the hen was conscious during conversation of the obscurity of her utterance, which also serves as a warning to Napoleon that her manner of expression may not be as clear as expected.

The second type of change in the translation of maxims as Table (1) shows is observing maxims flouted in the original. This happens when the translator opts for deleting the narrator's exploitation of a maxim and revealing the intended message:

5. ST: The others said of Squealer that he could tum black into white. (Orwell, 1945, Ch. 2)

TT: lidhālik yatafiqu jamī‘u al-ḥaywānāti 'alā al-qawli 'anna siqūlīr yaștațī'u 'an yaj'alaka tartakibu 'akhțā'an kabīrah. (Abdulghani, 2014, p. 26)

[Gloss: so all the animals agree that Squealer can convince you to commit foolish mistakes] 
6. ST: There were many more mouths to feed now. (Orwell, 1945, Ch. 9)

TT: wa-'inda qudūmi al-kharīfi jadda 'alā al-mazra'ati 'a' ḍā'an judud. (Abada, 2009, p. 95)

[Gloss: and when autumn came, there were new members in the farm.

In Example (5), the narrator tells that the pigs were successful in convincing the other animals about the rebellion and fundamentals of animalism, to the extent that the pig Squealer "could tum black into white". The narrator here uses a metaphorical expression that most obviously exploit the maxims of quality and manner. In addition, it emphasizes the meaning that "Squealer uses rhetoric to twist reality". This exploitation of the maxims on the part of narrator has been removed and replaced by a more explicit interpretation that observes the maxims ("Squealer can convince you to commit foolish mistakes"). In (6), the narrator tells that the farm has become unable to produce enough food for the growing number of animals. He/she uses the expression "more mouths", which flouts the maxims of quantity and manner, to refer to the growing number of animals. Similarly, this flouting which result from the metaphorical use of language has been deleted and replaced by the more explicit expression "new members", which clearly adheres more to the maxims.

The third kind of change that occurred to maxims is the increase of information quantity in the translated text. This has involved the insertion into the target text of new details retrievable from the context of the situation of the original text (see Pápai, 2004).

7. ST: "Comrade," said Snowball, "those ribbons that you are so devoted to are the badge of slavery. Can you not understand that liberty is worth more than ribbons?" (Orwell, 1945, Ch. 2)

TT: 'alā yumkuniki 'ann tataṣawarī 'ann li-al-ḥurriyati thamanan 'aghlā min hādhihi al-zīnati al-tāfihah? (Abdulghani, 2014, p. 27)

[Gloss: Can you not imagine that liberty has more value than these worthless/silly ribbons?]

In (7), Mollie is asking the pig Snowball whether she will be allowed to wear ribbons after rebellion, and he responds that she should not wear them as they symbolize slavery. Mollie in the story is a vain, silly and materialistic horse representing the bourgeoisie who did not fight much against the Russian government. Snowball in his question "Can you not understand that liberty is worth more than ribbons?" is indirectly scolding Mollie for showing more concern for ribbons than the revolution. The given translation inserts some new information inferable from the context ("worthless/silly") to describe "ribbons". The insertion of this new description into Snowball's response makes him more informative when communicating his message to Mollie.

\section{Translational orientations}

The data in Table (1) show that there are more cases of hedging maxims than the other two types of variation in the translation of maxims. This is manifested in both translations, but more remarkable in Abada's translation. This suggests that there is a trend in the two translations towards the linguistic realization of the narrator and speaking character's tacit awareness of conversational maxims while interacting (Horn, 2006, p. 25). There is a translational orientation towards lexicalizing the narrator and speaking character's assumption on the extent to which they are abiding by the maxims. In a fiction translation, one would then expect the speaking characters not only to communicate messages but also to inform each other "how informative, well-founded, relevant and perspicuous these messages are" (Grundy, 2013, p. 101). For instance, in comparis on with the untranslated text, Squealer in the translated text not only tells Clover that the beds are very comfortable but also relates to her that he is taking responsibility for the truth of what he is saying (see Example 2).
This greater use of maxim hedging in the translated narrative implicates a shift in the character-level relations (Black, 2006, p. 28), a tendency towards more consideration of politeness or face wants in a translated narrative (House, 1998). Maxim hedges like "I think", "The truth is ...", "The whole issue is ...", "As far as I know," etc., are commonly used as a strategy to soften the speaker's own opinion and show deference to the hearer's assumed greater understanding or experience (Leech, 2014, pp. 96-97). Thus, more frequent use of maxim hedges may suggest a greater awareness on the speaking characters' part of their face wants and greater consideration of the appropriateness of their utterances in the translated fictional dialogues. Not only giving notice to Mollie that Snowball is aware of the maxim, the insertion of a hedge on the maxim of relation, "by the way", into Snowball's utterance to Mollie "you do not need sugar" in Example (2) also reduces the impact of, and probably apologizes for. This sudden change in topic, making him look more polite than he is in the original.

This increased use of maxim hedges in the translated narrative may reflect a level of awareness of the maxims on the translators' part during their verbal (re)materialization of the original story (see Levý, 2011, pp. 27-31). A translation not only transposes a text from one language to another but also expresses the speech norms that guided the translator's choices during the contextualization or resetting of the original story. Among these speech norms are the tendency to express a state of mind or propositional attitudes (e.g., politeness, uncertainty or commitment to maxims). The translation process may be more a process of (re)narration in which translator takes part in constructing the world rather than a process of transferring accurately semantic values from the source to the target language (Baker, 2018b, p. 180). Translators narrativize events, and this process may 
involve, on the part of translators, a greater consciousness of conversational maxims and greater grammaticalization of this consciousness in the translated narrative.

The data in Table (1) also indicate that there are 54 cases where the translator observes a maxim that has been flouted in the original, while there are only 6 cases of a shift in the opposite direction, to flout a maxim that has been observed in the original. This gives us some insights into the character's interaction and their preferred style of negotiating thoughts and feelings (see Şerban, 2013, p. 220; Lambrou, 2014, pp. 143-144). Compared to the original, characters seem now to like to interact and communicate messages by observing rather than flouting maxims. They now prefer explicitation to implication (Blum-Kulka, 2004). For example, the animals would flout maxims and say Squealer "could tum black into white", but now they are more explicit and simply say that Squealer "can convince you to commit foolish mistakes" (see Example 5). This explicitation pattern can only manifest a greater simplicity and concision in Orwell's language or writing style (Fowler, 2009, pp. 63-68). Since one of the most distinctive characteristics of Orwell's linguistic style in the novel is his simple, clear and concise language, this tendency towards a more simplified and less ambiguous language in translation (Toury, 2012, p. 306) leads to a translated narrative that maintains the overall style or feel of the original (see Munday, 2008, pp. 19-20). One may then look at this pattern of explicitation or simplification as textual traces of the translator's (conscious or subconscious) attempts to reconstruct the stylistic choices the original author made. In other words, this may be an instance of a translator's voice complementing an authorial voice (Munday, 2008, pp. 14-16), or of a translator, relying on his/her cognitive context, reconstructing the original author's poetics (Boase-Beier, 2018, pp. 199-200, see Abualadas, 2019a, p. 275).

This orientation towards observing rather than flouting maxims in the translated narrative affects not only character-level interactions but also the higherlevel (narrator-reader) ones (Black, 2006, p. 29). The narrator's flouting of maxims would normally communicate a message to the reader, through an inductive inference the reader (given rational cooperation) draws as to the intended implicature. The translator's tendency to observe maxims, which the narrator flouts in the original (e.g., the translation of "more mouths" as "new members" in Example 6, would actually avoid the target reader this inductive inference process. Such a pattern of shift can only be indicative of fewer narrator-reader implicatures and a lesser/weaker narrator-reader cooperation in the translated narrative. The text's persuasion power is claimed to improve if a reader accepts the implied meanings that are not explicitly stated, which is often referred to as subliminal persuasion (Lakhani, 2008, see Ying \& Zhao, 2018, p. 117). This tendency towards fewer narrator-reader implicatures in the translated narrative may then result in losing some of the narrative's subliminal messages or weakening the narrator's subliminal language. Such patterns of shift can generally suggest a less stylistically engaging text, hence a reduced level of engagement on the part of the target reader compared to that of the original reader (Boase-Beier, 2018, pp. 201-203).

The data in Table (1) indicate that there are 65 instances of insertion into the translated utterance of information inferable from the cognitive context (Saldanha, 2008, pp. 21-23). At the level of the character-to-character interaction, this suggests characters offering more informative conversational contributions than those of the original. When Snowball advises Mollie not to wear ribbons (as they are a symbol of slavery), he now further tells her that these ribbons are silly and worthless (see Example 7). The articulation of such contextual information as "silly and worthless" reflects speaking characters showing an awareness of or need for an increased level of proposition informativeness, a level assumed to be appropriate or adequate (not more or less than needed) for the purpose of the conversation (see Bach, 2012, pp. 63-64). If we assume that in an ordinary situation a speaker is expected to speak in "the most economical way possible" or give only "the minimum required" (Chapman 2011, pp. 91-920), and so should a fictional character, the verbalization of extra contextual information in characters' interactions would express an increase in the minimum desired level of informativeness compared to the original.

This lexicalization of extra optional contextual information in the translated narrative may have an effect upon "the readability and ease of comprehension" of the translated narrative (Saldanha, 2008, pp. 31-32). It generally adds to the mutual cognitive environment of the narrator and reader (see Gutt, 2010, pp. 27-28), thus facilitating the communication of narrator-reader implicatures (Black, 2006, p. 29). This change of information from implicit into explicit status reflects the translator's voice or mediating role in the translated narrative (Munday, 2008, pp. 12-14). It can be looked at an instance of self-referentiality or metalinguistic use of language, when language describes or clarifies language (Hermans, 1996, p. 29; Saldanha, 2008, pp. 23-24), which is sometimes assumed to be related to the translators' assumption of their role as literary mediators (Saldanha 2008: 31).

\section{CONCLUSION}

The present study has analyzed Grice's maxims and cooperation in two Arabic translations of Animal Farm and revealed several patterns of change. At the character-level interaction, the translated narrative shows a more frequent use of maxim hedges and a more lexicalized awareness of, or commitment to, maxims than the original does. This suggests interactions involving more manifestations of social/interpersonal relationships, politeness and metalinguistic functions (House, 1998; Hatim and Mason, 2013; Baker, 2018a). 
In addition, compared to the original, the characters in the translated narrative prefer to provide a more informative response as well as to observe rather than flout maxims. They show a preference for explication over implication and directness over indirectness while interacting (Morini, 2008; Gutt, 2010)

At the higher-level (narrator-reader or text-reader) interaction, the translational orientation towards less flouting and/or more observance of maxims suggests fewer narrator-reader implicatures and potentially a lesser degree of reader cooperation with the translated narrative (Malmkjær, 2003, 2005). This suggests a translational style that invites a lesser level of cognitive engagement compared to that of the original (BoaseBeier, 2018). The translated narrative exhibits a higher level of explicitness (Blum-Kulka, 2004) and an increased informativeness that may contribute to the ease and/or minimization of processing efforts while reading. This makes the "conciseness of form and simplicity of language" of the original narrative more visible to the reader (Fowler, 2009, p. 63).

The increased use of maxim hedges may reflect the translator's awareness of or commitment to conversational maxims during the re-narration process (Baker, 2018b). The increased level of explicitness and informativeness may also signal the translator's (intentional or unintentional) attempts to provide more contextual information or cues to interpretation (Malmkjær, 2004; Saldanha, 2008), or his/her mediating role while constructing or reconstructing the authorial and narrative voice (Munday, 2008; Saldanha, 2008). This may be a normal practice in translation if we assume that "the message coming from the translation is relayed in a different code that bears the translator's print" (Munday, 2008, p. 13). Finally, in spite of the possible universality of conversational maxims, linguistic and stylistic preferences vary across cultures and text types, the analysis of which would be important for explaining the reason modifications are made in translation.

\section{REFRENCES}

Abada, S. (2009). Animal Farm (Arabic translation). Morocco and Lebanon: The Arab Cultural Centre.

Abdulghani, M. (2014). Animal Farm (Arabic translation). Cairo: Dar El Shorouk.

Abualadas, O. (2019a). Person deixis and point of view in English-Arabic fiction translation: A trend towards repositioning the narrator, characters and readers. International Journal ofArabic-English Studies, 19(2), 263-280. doi: 10.33806/ijaes 2000.19.2.2

Abualadas, O. (2019b). Deictic shifts in fiction translation: Evidence of a more marked perspective in the translated narrative. Indonesian Journal of Applied Linguistics, 9(2), 424-433. doi: 10.17509/ijal.v9i2.20240

Abualadas, O. (2019c). Systematic shifts in implicatures in two Arabic translations of Ernest Hemingway's
A Farewell to Arms. International Journal of Comparative Literature \& Translation Studies, 7(3), 65-73. doi: 10.7575/aiac.ijc lts.v.7n.3p.65

Bach, K. (2012). Saying, meaning, and implicating. In K. Allan \& K. Jaszczolt (Eds.), Cambridge handbook ofpragmatics (pp. 47-67). Cambridge: Cambridge University Press.

Baker, M. (2018a). In otherwords: A coursebook on translation $\left(3^{\text {rd }}\right.$ edn.). London and New York: Routledge.

Baker, M. (2018b). Narrative analysis and translation. In K. Malmkjær (Ed.), The Routledge handbook of translation studies and linguistics (pp. 179-193). London and New York: Routledge.

Black, E. (2006). Pragmatic stylistics. Edinburgh: Edinburgh University Press Ltd.

Bloom, H. (2006). Bloom's guides: Animal Farm. New York: Infobase Publishing.

Blum-Kulka, S. (2004). Shifts of cohesion and coherence in translation. In L. Venuti (Ed.), The translation studies reader (pp. 298-313). London and New York: Routledge.

Boase-Beier, J. (2014). Stylistic approaches to translation.London and New York: Routledge.

Boase-Beier, J. (2018). Stylistic and translation. In K. Malmkjær (Ed.), The Routledge handbook of translation studies and linguistics (pp. 194-207). London and New York: Routledge.

Bousfield, D. (2014). Stylistics, speech acts and im/politeness theory. In M. Burke (Ed.), The Routledge handbook of stylistics (pp. 118-135). London and New York: Routledge.

Chapman, S. (2011). Pragmatics. Houndmills, Basingstoke: Palgrave Macmillan.

Culpeper, J. (2014). Language and characterisation: People in plays and othertexts. London and New York: Routledge.

Fowler, R. (2009). Animal farm. In R. Fowler (Ed.), Bloom's modern critical interpretations: Animal farm (pp. 59-78). New York: Infobase Publishing.

Frawley, W. (1984). Prolegomenon to a theory of translation. In W. Frawley (Ed.), Translation: Literary, linguistic and philosophical perspectives (pp. 159-175). Newark: University of Delaware Press.

Grice, P. (1975). Logic and conversation. In P. Cole \& J. Morgan (Eds.), Syntax and semantics: Speech acts (pp. 41-58). New York: Academic Press.

Grundy, P. (2013). Doing pragmatics. London and New York: Routledge.

Gutt, E-A. (2010). Translation and relevance: Cognition and context. London and New York: Routledge.

Hatim, B., \& Mason, I. (2013). Discourse and the translator. London and New York: Routledge.

Hatim, B. (2000). Communication across cultures: Translation theory and contrastive text linguistics. Exeter: University of Exeter Press. 
Hermans, T. (1996). The translator's voice in translated narrative. Target, 8(1), 23-48. doi: 10.1075/target.8.1.03her

Horn, L. (2006). Implicature. In L. Horn \& G. Ward (Eds.), The handbook ofpragmatics (pp. 1-29). Oxford: Blackwell Publishing.

House, J. (1998). Politeness and translation. In L. Hickey (Ed.), The pragmatics of translation (pp. 54-71). Clevedon: Multilingual Matters.

Lakhani, D. (2008). Subliminal persuasion: Influence and marketing secrets they don't want you to know. Hoboken, NJ: John Wiley and Sons.

Lambrou, M. (2014). Stylistics, conversation analysis and the cooperative principle. In M. Burke (Ed.), The Routledge handbook of stylistics (pp. 136154). London and New York: Routledge.

Leech, G., \& Short, M. (2007). Style in fiction $\left(2^{\text {nd }}\right.$ edn.). UK: Pearson Education Limited.

Leech, G. (2014). The pragmatics of politeness. Oxford: Oxford University Press.

Levý, J. (2011). The art of translation. Amsterdam and Philadelphia: John Benjamins.

Malmkjær, K. (2003). What happened to God and the angels: an exercise in translational stylistics. Target, 15(1), 37-58. doi: 10.1075/target.15.1.03mal

Malmkjær, Ki. (2004). Translational stylistics: Dulcken's translations of Hans Christian Andersen. Language and Literature, 13(1), 13-24. doi: 10.1177/0963947004039484

Malmkjaer, Ki. (2005). Linguistics and the language of translation. Edinburgh: EUP.

Mason, I. (2000). Audience design in translation. The Translator, 6(1), 1-22. doi: 10.1080/13556509.2000.10799053

Morini, M. (2008). Outlining a new linguistic theory of translation. Target, 20(1), 29-51. doi: 10.1075/target.20.1.03mor

Morini, M. (2013). The pragmatic translator: An integral theory of translation. London: Blooms bury.

Munday, J. (2008). Style and ideology in translation. New York and London: Routledge.

Orwell, G. (1945). Animal farm. London: Secker and Warburg.

Pápai, V. (2004). Explicitation: A universal of translated text? In A. Mauranen \& P. Kujamäki (Eds.), Translation universals: Do they exist? (pp. 143164). Amsterdam and Philadelphia: John Benjamins.

Pym, A. (2014). Exploring translation theories. $\left(2^{\text {nd }}\right.$ edn.). London: Routledge.

Saldanha, G. (2008). Explicitation revisited: Bringing the reader into the picture. Trans-kom, 1(10), 2035.

Şerban, A. (2013). Linguistic approaches in translation studies. In C. Millán \& F. Bartrina (Eds.), The
Routledge handbook oftranslation studies (pp. 213-227). London and New York: Routledge.

Shreve, G. (2018). Text linguistics, translating, and interpreting. In K. Malmkjær (Ed.), The Routledge handbook oftranslation studies and linguistics (pp. 165-178). London and New York: Routledge.

Sperber, D., \& Wilson, D. (1995). Relevance: Communication and cognition. Oxford: Blackwell Publishing.

Toury, G. (2012). Descriptive translation studies-and beyond. Amsterdam and Philadelphia: John Benjamins.

Wales, K. (2014). A dictionary of stylistics. London and New York: Routledge.

Warner, C. (2014). Literary pragmatics and stylistics. In M. Burke (Ed.), The Routledge handbook of stylistics (pp. 362-377). London and New York: Routledge.

Wierzbicka, A. (2003). Cross-cultural pragmatics: The semantics of human interaction. Berlin: New York: Mouton de Gruyter.

Ying, C., \& Zhao, Y. (2018). Implicature and presupposition in translation and interpreting. In K. Malmkjær (Ed.), The Routledge handbook of translation studies and linguistics (pp. 107-120). London and New York: Routledge.

Appendix

The Library of Congress Transliteration System for Arabic Consonants and Vowels

\begin{tabular}{|c|c|c|c|}
\hline $\begin{array}{l}\text { Arabic } \\
\text { symbol }\end{array}$ & Transliteration & $\begin{array}{l}\text { Arabic } \\
\text { symbol }\end{array}$ & Transliteration \\
\hline$\Leftrightarrow$ & & ف ف & $\mathrm{f}$ \\
\hline T & $\mathrm{a}$ & ق & $\mathrm{q}$ \\
\hline ب & $\mathrm{b}$ & 5 & $\mathrm{k}$ \\
\hline ت & $\mathrm{t}$ & $J$ & 1 \\
\hline$\dot{H}$ & th & 5 & $\mathrm{~m}$ \\
\hline ج & $\mathrm{j}$ & $\dot{ن}$ & $\mathrm{n}$ \\
\hline$\tau$ & ha & $ه$ & $\mathrm{~h}$ \\
\hline$\dot{\tau}$ & kh & 9 & $\mathrm{w}$ \\
\hline 2 & $\mathrm{~d}$ & ي & $\mathrm{y}$ \\
\hline$\dot{j}$ & $\mathrm{dh}$ & 1 & $\overline{\mathrm{a}}$ \\
\hline J & $\mathrm{r}$ & 6 & $\mathrm{a}$ \\
\hline$j$ & $\mathrm{Z}$ & ي & $\overline{1}$ \\
\hline س & $\mathrm{s}$ & ? & $\mathrm{i}$ \\
\hline ش ش & sh & 9 & $\overline{\mathrm{u}}$ \\
\hline ص & Ș & $\dot{8}$ & $\mathrm{u}$ \\
\hline ض & $\bar{d}$ & 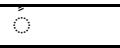 & an \\
\hline$b$ & ț & @ & in \\
\hline ظ & $\mathrm{Z}$ & 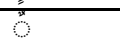 & un \\
\hline$\varepsilon$ & & 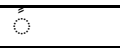 & an \\
\hline$\dot{\varepsilon}$ & gh & & \\
\hline
\end{tabular}

